\title{
DETERMINATION OF THE NO OBSERVABLE EFFECT LEVEL (NOEL) OF FOUR COMMONLY USED FORESTRY HERBICIDES ON TOMATOES
}

\author{
J.W. RAY, A.L. VANNER, B. RICHARDSON and G. COKER \\ Plant Protection Chemistry, New Zealand Forest Research Institute, \\ Private Bag 3020, Rotorua
}

\begin{abstract}
No Observable Effect Levels were determined for four commonly used forestry herbicides on glasshouse grown tomatoes. For metsulfuron and glyphosate, NOELs based on visual symptoms were lower than those for dry weight production (ED5). For triclopyr the values were similar. The rates used for clopyralid/picloram mixtures allowed for a visual NOEL to be determined but were too high for the determination based on dry weight. The value of the NOEL varies with the method used to determine it.
\end{abstract}

Keywords: tomatoes, herbicides, NOEL

\section{INTRODUCTION}

When applying herbicides it is not possible to ensure that all the spray released will land on the target. Major factors affecting the quantity of spray moving off site (drift) include: droplet size, spray release height, and meteorological conditions, especially wind speed. The validated computer-based spray dispersion model, FSCBG (Teske $e t$ al. 1993), can be used to predict on- and off-site deposition following the aerial application of herbicides. Off-target deposition decreases with increasing distance from the sprayed block. At very low doses, herbicides are thought to have no effect on plants but as the dose is increased, beyond a certain level, growth reduction occurs. The "No Observable Effect Level" (NOEL) is usually defined as the highest dose having no effect on the growth of the test plant.

Provided the NOEL is known for a particular plant/herbicide combination, it is possible to use FSCBG to predict the size of buffer zone down wind of the spray area to prevent drift from the spray zone causing damage. Plans are underway to combine FSCBG with models of plant/herbicide responses in a user friendly computer model (SpraySafe Manager DSS, Richardson et al. 1995). This will allow field spray operation controllers to predict the buffer zone needed to prevent damage occurring in a sensitive crop adjacent to the spray operation. The trials described in this paper were undertaken to provide data for the dose-response database of the proposed system.

\section{Production of test plants}

\section{METHODS}

Tomato plants (var Russian Red) raised in a glasshouse from seed were transplanted into $600 \mathrm{ml}$ square pots, containing a commercial potting mix (Yates Bloom). Herbicides were applied when the plants were approximately $20 \mathrm{~cm}$ tall.

\section{Application of herbicide}

Herbicides were applied using a "track sprayer" built at FRI. The sprayer consisted of an aspirated cabinet containing a variable speed conveyer belt with a nozzle mounted above it. Tomato plants were placed on the conveyor belt which transported them under a TeeJet $80015 \mathrm{E}$ nozzle, operated at $200 \mathrm{kPa}$. Belt speed and nozzle emission were constantly monitored. The nozzle height was adjusted to $50 \mathrm{~cm}$ above the average plant height. The swath width produced by the nozzle was measured 
at average plant height and the belt speed adjusted to give an application rate of 200 litres/ha.

The treatments are listed in Table 1.

TABLE 1: Herbicides applied to tomatoes in a total spray volume of $200 \mathrm{l} / \mathrm{ha}$.

\begin{tabular}{lll}
\hline Herbicide & Additive & Range of rates \\
\hline metsulfuron & $0.1 \%$ Pulse & $0.0006-18 \mathrm{~g} / \mathrm{ha}$ \\
glyphosate & $0.25 \%$ Pulse & $0.036-1080 \mathrm{~g} / \mathrm{ha}$ \\
triclopyr & $0.5 \%$ Boost & $0.06-1800 \mathrm{~g} / \mathrm{ha}$ \\
clopyralid/picloram & $0.25 \%$ Boost & $0.00675 / 0.0045-225 / 150 \mathrm{~g} / \mathrm{ha}$ \\
clopyralid/picloram & $0.25 \%$ Boost & $0.000225 / 0.00015-2.25 / 1.5 \mathrm{~g} / \mathrm{ha}$ \\
\hline
\end{tabular}

Each herbicide was applied at ten different rates and each rate was applied to ten tomato plants. In addition, Pulse or Boost applications, at $0.25 \%$ and $0.5 \%$ respectively, were each applied to ten plants. Plants were harvested, at ground level, and dried,18 days after spraying in the first series of experiments and 25 days in the repeat clopyralid/picloram trial. Their dry weight production was compared with the average dry weight of 40 unsprayed plants.

\section{Estimation of NOEL}

The visual NOEL was defined as the highest herbicide dose that could be applied without visual symptoms being observable at the time of harvesting.

A quantitative NOEL was calculated based on dry matter production. Plotting the dry matter against the log of herbicide concentration should give a sigmoid curve described by a logistic model (Streibig 1988), in which dry matter production $\left(\underline{U}_{\mathrm{S}}\right)$, is a function of dose $\left(\underline{z}_{s}\right)$ of herbicide and can be described by the logistic model:

$$
\underline{\mathrm{U}}_{\mathrm{s}}=(\underline{\mathrm{D}}-\underline{\mathrm{C}}) /\left(1+\exp \left(-2\left(\underline{\mathrm{a}}+\underline{\mathrm{b}}^{*} \log \left(\underline{\mathrm{z}}_{\mathrm{s}}\right)\right)\right)\right)+\underline{\mathrm{C}} ; \underline{\mathrm{b}}<0
$$

where $\underline{D}$ denotes the upper and $\underline{C}$ the lower limit of production. The upper limit of production, (D), was normalised. In the linear term $\left(\underline{\mathrm{a}}+\underline{\mathrm{b}}^{*} \log \underline{\mathrm{z}_{\underline{ }}}\right)$, the parameter $\underline{\mathrm{a}}$ determines the horizontal location of the steepest part of the curve and $\underline{b}$ is proportional to the slope of the curve in the vicinity of the point of inflexion. The difference in weight described by the term ( $\underline{D}-\underline{C})$ has been normalised to 1 by calculating all dry weight as a proportion of that of the untreated control. Data were fitted to this model using a non-linear least squares regression. NOEL can be defined using different criteria (Streibig 1989). In this study the ED5 (dose giving a 5\% reduction in yield) was used.

\section{RESULTS}

Neither additive, when applied alone, induced any visible symptoms or a reduction in dry weight production. Metsulfuron and glyphosate both produced chlorosis of the terminal leaves at rates above the NOEL. Some distortion of the terminal leaves was also apparent in the case of metsulfuron. High rates of triclopyr induced typical auxin-like distortion of plants which was apparent 4 hours after spraying. At higher rates the outer layers of the stem peeled revealing wart-like growths. Proliferation of the cells on the stem was apparent at all rates above the NOEL. Treatment with high rates of clopyralid/picloram produced distortion similar to that of triclopyr but with no growths on the stem. After 16 days the terminal leaves appeared more pointed, whilst at higher rate the flowers buds were distorted, being pineapple shaped. These later symptoms were ascribed to the action of the picloram.

The logistic model fitted the data reasonably well (Fig. 1) apart from that generated with the clopyralid/picloram mixes. In these cases the value of the upper asymptote was less than one, suggesting that inhibition was occurring even at the lowest rates applied. 


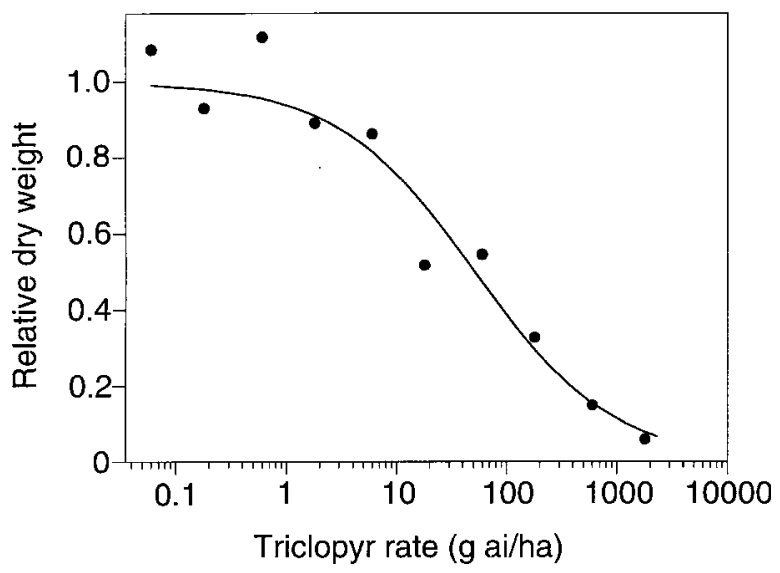

FIGURE 1: Fitted dose response curve for triclopyr. Results of mean dry weight determinations are shown by the plotted points.

The visual and calculated NOELs are given in Table 2.

Dry weight production of the tomatoes treated with the lowest rate of clopyralid/ picloram in both experiments failed to equal that of the unsprayed controls.

TABLE 2: NOELs based on visual assessment and dry weight determinations for tomatoes.

\begin{tabular}{lll}
\hline Herbicide & Visual NOEL & ED 5 (dry weight) \\
\hline metsulfuron & $0.018 \mathrm{~g} / \mathrm{ha}$ & $0.2654 \mathrm{~g} / \mathrm{ha}$ \\
glyphosate & $3.6 \mathrm{~g} / \mathrm{ha}$ & $14.54 \mathrm{~g} / \mathrm{ha}$ \\
triclopyr & $0.6 \mathrm{~g} / \mathrm{ha}$ & $0.7 \mathrm{~g} / \mathrm{ha}$ \\
clopyralid/picloram & $6.75 / 4.5 \mathrm{mg} / \mathrm{ha}$ & $<0.00675 \mathrm{~g} / \mathrm{ha}$ \\
clopyralid/picloram & $22.5 / 15.0 \mathrm{mg} / \mathrm{ha}$ & $<0.000225 \mathrm{~g} / \mathrm{ha}$ \\
\hline
\end{tabular}

\section{DISCUSSION}

The NOEL, for a given plant/herbicide combination is not an absolute value. It will vary with temperature, humidity, and also the stage/age of the crop. In general, herbicide effectiveness increases with increasing temperature and humidity and decreases with the increasing age of the test plant, however dose response curves usually remain parallel. These changes in susceptibility are reflected by displacement of the dose response curves along the " $x$ " axis, the shape of the curves remains unchanged (Jensen and Kudsk 1988). Herbicide effectiveness is usually measured by plotting either the fresh or dry weight of some particular part of the test plant, some time after spraying, against the logarithm of the herbicide dose. Sometimes plants treated with subtoxic doses of a herbicide exceed the growth of the untreated control (Streibig 1988). However Pestemer and Günther (1993) are of the opinion that this stimulation of growth can be ignored when determining NOELs and suggest that it might be more appropriate to measure a "no observed adverse effect level" (NOAEL).

No significant stimulation of growth was observed with the tomatoes treated with any of the herbicides tested. The value for the NOEL depends on the criteria used to define the no effect level. Visual estimation of the NOEL for metsulfuron and glyphosate proved more sensitive than that determined by measurement of dry weight 
production. For the visual NOEL the value is set by the response of the most sensitive plant within the replicates which comprise that doseage level. If the criterion for defining NOEL is the ED5 level, the average dry weight production of all the plants within a replicated group is used and the value may be different. (The difference is probably due to the ED5 being based on an average of 10 plants whereas the most sensitive plant would be identified visually.) For triclopyr, the NOEL based on visual symptoms and dry weight production were similar. The dry weight production of plants treated with the clopyralid/picloram was reduced by herbicide rates much lower than those that produced visual effects.

The conditions used in these experiments, where plants have been grown in a glasshouse, have resulted in lower NOELs than those reported by other authors for field grown tomatoes. Smith and Geronimo (1984) reported a significant yield reduction in field grown tomatoes with triclopyr at $112 \mathrm{~g}$ ai /ha but not at $11.2 \mathrm{~g}$ ai/ha. Clopyralid and picloram, applied separately, produced significant yield losses at 112 and $11.2 \mathrm{~g}$ ai/ha respectively. Lucus and Lobb (1987) found that yield reductions occurred when clopyralid was applied at $1000 \mathrm{~g}$ ai/ha, but visual symptoms occurred with rates as low as $10 \mathrm{~g}$ ai/ha in field grown tomatoes. Lobb (1989) reported, again for field grown tomatoes, that $50 \mathrm{~g}$ ai/ha of triclopyr caused significant visual effects and yield reductions. Glyphosate produced yield reductions at $500 \mathrm{~g}$ ai/ha and visual symptoms at $50 \mathrm{~g}$ ai/ha and metsulfuron significant yield reduction and visual symptoms at $0.1 \mathrm{~g}$ ai/ha.

Dose response curves will be used in the database of the SpraySafe Manager DSS to predict the width of buffer zones, rather than the more subjective estimate of visual damage. The use of plants which are more sensitive than field grown ones will increase the safety factor built into the Spray Safe Manager DSS. This margin could be further increased by using the ED5 level based on the lower 95\% confidence level instead of the mean used in this study.

\section{REFERENCES}

Lobb, P.G., 1989. Response of potatoes, onions and tomatoes to herbicides used for brushweed control. Proc. 42nd N.Z. Weed and Pest Control Conf.: 251-253.

Lucas, W.J. and Lobb, P.G., 1987. Response of potatoes, tomatoes, and kumaras to foliar applications of MCPA, MCPB, 2,4-D, clopyralid and amitrole. Proc. 40th N.Z. Weed and Pest Control Conf.: 59-63.

Jensen, P.K. and Kudsk, P., 1988. Prediction of herbicide activity. Weed Res. 28, 473 478.

Pestemer, W. and Günther, P., 1993. No observable effect level (NOEL). Pp 137-152 In: Herbicide Bioassays, J.C. Streibig and P. Kudsk (Eds), CRC Press.

Richardson B., Thistle, H., Ray, J.W. and Barry, J., 1995. Aerial application simulation models: The next generation.Second Int. Conf. on Forest Vegetation Management, NZ FRI Bulletin No 192: 295-297.

Smith, L.L. and Geronimo, J., 1984. Response of seven crops to foliar applications of six auxin-like herbicides. Down to Earth 40: 25-32.

Streibig, J.C., 1989. The herbicide dose-response curve and the economics of weed control. Brighton Crop Prot. Conf. Weeds-1989: 927-935.

Teske, M.E., Bowers, J.F., Rafferty, J.E. and Barry, J.W., 1993. FSCBG: an aerial spray dispersion model for predicting the fate of released material behind aircraft. Environ. Toxicol. and Chem. 12: 453-464. 